Canadian University Music Review

Revue de musique des universités canadiennes

\title{
In Memoriam Alan Lessem
}

\section{Gail Dixon}

Volume 11, numéro 2, 1991

URI : https://id.erudit.org/iderudit/1014101ar

DOI : https://doi.org/10.7202/1014101ar

Aller au sommaire du numéro

Éditeur(s)

Canadian University Music Society / Société de musique des universités

canadiennes

ISSN

0710-0353 (imprimé)

2291-2436 (numérique)

Découvrir la revue

Citer ce document

Dixon, G. (1991). In Memoriam Alan Lessem. Canadian University Music Review

/ Revue de musique des universités canadiennes, 11(2), vi-ix.

https://doi.org/10.7202/1014101ar

(c) Canadian University Music Society / Société de musique des universités canadiennes, 1991
Ce document est protégé par la loi sur le droit d'auteur. L’utilisation des services d'Érudit (y compris la reproduction) est assujettie à sa politique d'utilisation que vous pouvez consulter en ligne.

https://apropos.erudit.org/fr/usagers/politique-dutilisation/ 


\section{IN MEMORIAM ALAN LESSEM}

After a long and courageous battle with cancer, Alan Lessem passed away on 6 October 1991 in Toronto. His death has saddened all who are fortunate enough to have known him, for Alan was a truly exceptional man. Born in Salisbury, Rhodesia (now Harare, Zimbabwe) on November 29 1940, he obtained his early training at the University of Cape Town (B.Mus., B.A., 1963). He then moved to England where he studied at Cambridge University (M.Litt. 1967). The international flavour of his background was further enhanced by several years as a piano and theory instructor at the Rubin Academy in Israel, followed by doctoral studies in the United States (Ph.D., University of Illinois, Urbana, 1973). In 1970, he finally came "home" to York University, which has been the focus of his professional life since that time. Alan was an extraordinarily valuable member of the academic community at York. As an administrator, he served as Chairman of the Department of Music (1975-83), as Associate Dean of the Faculty of Fine Arts (1985-88), as Acting Director of the Graduate Programme in Music (1988), and as Acting Dean of the Faculty of Fine Arts (1989). As a scholar, Alan's work is well known and universally respected. The remarkable breadth of his intellectual inquiry is perhaps a reflection of his international background. His scholarly contributions - two books, several dozen periodical articles and reviews and numerous lectures and colloquia - are a lasting testament to his integrity, perspicacity and lucidity as a scholar. As a teacher, Alan was much loved and respected. A true mentor to his students, he was able to offer both encouragement and constructive criticism, all tempered with his dry sense of humour.

Alan was committed to standards of academic excellence. Genuinely interested in the intellectual endeavours of others, he was highly respected by other humanists. What set him apart as a person was that same integrity with which he conducted his scholarly work and his administrative duties. He was committed, honest, tenacious, modest and decent in all facets of his life. His tenacity was reflected in the last few months in the way in which he continued researching and writing scholarly papers, playing chamber music with his colleagues, and teaching classes at York as recently as September.

In June, 1990, Alan was appointed by the Canadian University Music Society as English Editor of the Canadian University Music Review. He quickly proved himself to be an exceptionally fine editor, offering guidance, encouragement, and illuminating insights to contributors. So conscientious was he that even in the last few months of his illness he continued to discharge all of his duties as editor to the full. The Society is deeply grateful for his contributions. 
On behalf of the Canadian University Music Society, I extend sincere sympathy to Alan's wife Evelyn and his two children. May they take comfort from the knowledge that they are not alone in mourning the passing of this warm, compassionate, and truly wonderful human being.

Gail Dixon, President 


\section{IN MEMORIAM ALAN LESSEM}

Au terme d'un long et courageux combat contre le cancer, Alan Lessem est décédé le 6 octobre 1991 à Toronto. Sa mort a attristé tous ceux qui ont eu la chance de le connaître, car Alan était un homme vraiment exceptionnel. Né à Salisbury, Rhodésie (maintenant Harare, Zimbabwe), le 29 novembre 1940, il reut sa premiére formation à l'Université de Cape Town (B. Mus., B.A., 1963). 11 s'installa ensuite en Angleterre et étudia à l'Université de Cambridge (M. Litt., 1967). L'ampleur internationale de ses acquis s'enrichit en outre de plusieurs années d'enseignement du piano et de la théorie à la Rubin Academy d'Israël, puis d'études de doctorat aux États-Unis (Ph.D., Université de I'lllnois, Urbana, 1973). En 1970, il entrait finalement « chez lui » à l'Université York, foyer de sa vie professionnelle depuis lors.

Alan était un membre extraordinairement précieux de la communauté académique de York. Auplan de l'administration, il occupa les postes de doyen du Département de musique (1975-83), de vice-doyen de la Faculté des Beaux-arts (1985-88), de directeur intérimaire des Études supérieures en musique (1988) et de doyen intérimaire de la Faculté des Beaux-arts (1989). Au chapitre de la recherche, ses travaux sont universellement reconnus. Et sans doute que la remarquable étendue de son bagage intellectuel est liée à son expérience internationale. Les apports d'Alan au savoir - deux livres, des douzaines d'articles et de comptes rendus, nombre de conférences et de participations à des colloques - constituent le testament durable de son intégrité, de sa perspicacité et de sa lucidité de chercheur. Au plan de l'enseignement, Alan était un professeur trés aimé et trés respecté. Véritable mentor pour ses étudiants, il savait leur offrir et encouragement et critique constructive, sans omettre son humour de " pince-sans-rire ».

Alan était un modéle d'excellence académique. Profondément intéressé par les tâches intellectuelles d'autrui, il était hautement apprécié de ses collègues humanistes. Son côté solitaire lui venait de cette même intégrité avec laquelle il menait son travail de chercheur et ses devoirs administratifs. Il était engagé, honnête, tenace et modeste dans toutes les facettes de sa vie. Preuve de toutes ces qualités, il continua, jusqu'en septembre dernier, de mener ses recherches, d'écrire, de faire de la musique de chambre avec ses collègues et d'enseigner à York.

En juin 1990, Alan recevait de la Société de musique des universités canadiennes le mandat d'éditeur anglais de la Revue de musique des universités canadiennes. Très vite, il se révéla être un éditeur exceptionnellement fin, sachant guider les collaborateurs de la revue par des encouragements et des conseils éclairants. Il 
était si conscienceieux qu'il assuma jusqu'au bout, même dans les tout derniers mois de sa maladie, l'entière responsabilité de ses tâches éditoriales. La Société lui en est profondément reconnaissante.

Au nom de la Société de musique des universités canadiennes, j'adresse mes sincères condoléances à l'épouse d'Alan, Evelyn, ainsi qu'à leurs deux enfants. Puissent-ils se consoler à l'idée qu'ils ne sont pas seuls à pleurer la disparition de cet être chaleureux, sensible et réellement merveilleux.

Gail Dixon, présidente. 